\title{
Proximate Analyses of Different Samples of Egg Shells Obtained from Sokoto Market in Nigeria
}

\author{
Nasruddeen Yusuf Al-awwal ${ }^{1}$, Usman Lado Ali $^{2}$ \\ ${ }^{1,2}$ Department of Chemistry, SRM University, Kattankulathur 603203, India
}

\begin{abstract}
The proximate and mineral compositions of the eggshells obtained from Sokoto State Central Market in Nigeria as labeled sample A for poultry fowl eggshell, sample B for guinea fowl eggshell, sample C for Chicken and sample D for pigeon eggshell. The result showed that the eggshells as labeled contained $(1.0 \pm 0.007 \%, 2.0 \pm 0.02 \%, 0.5 \pm 0.03 \%$, and $3.0 \pm 0.01 \%$ moisture content respectively). Ash content $(47 \pm 0.015 \%, 47.5 \pm 0.02 \%, 43.5 \pm 0.0316 \%$ and $1.33 \%$ respectively. The crude protein reveals $(1.4 \pm 0.4 \%$, $1.6 \pm 0.2 \%, 1.35 \pm 0.4 \%$ and $1.33 \pm N . D)$ for the samples $A-D$ respectively. The crude fibre content ranges from $5.0 \pm 0.5 \%$ sample $A$ to


ranges from $79.3 \%$ in sample $B$ to $69.74 \%$ in sample $D$. For the mineral elements, sodium in $\mathrm{mg} / 100 \mathrm{~g}$ ranges from $5.625 \pm 0.2$ in sample $A$ to $4.74 \pm 1.0$ in sample $C$. For calcium in $m g / 100 g$ is $0.475 \pm 0.2$ in sample $B$ to $0.325 \pm 0.2$ for sample D. the percentage concentration of minerals element was determined using flame photometer (Corning 400). In short, the mineral compositions are more or less high in concentration compared to the daily recommended allowance. And the eggshells could be used as a food source in alleviating the local deficiencies of these elements during formulating birds and other animal feeds (Chicken in particular) and can also be used in pest control.
\end{abstract}

Keyword:eggshell, fibre, moisture, ash, mineral elements, protein and carbohydrate.

\section{Introduction}

Eggshells are the hardest part of the reproductive cells of a bird. They are often described as a blue print of another animal(Chicken) with sufficient building materials to make it. Eggshells vary widely in texture. The eggshell is secreted most actively during the last 15 hours that the egg spends in uterus. It is predominantly made up of calcium carbonate and glycoprotein matrix (2\%). The crystalline part of the shell consists of columns materials embedded in the outer shell membrane. Pores that extend from the outside of the egg to the shell membranes and allow for gas exchange by the embryo separate these columns. Outside the shell is a thin proteinaceous layer, the cuticle that may block the entrance of bacteria. [1]

Most good quality eggshells from commercial layers contain approximately 2.2 grams of calcium in the form of calcium carbonate. About $95 \%$ of the dry eggshell is calcium carbonate weighing 5.5 grams. The average eggshell contains about $29-35 \%$ water, $1.4-4 \%$ protein, $0.1-0.2 \%$ crude fat, $89.9-91.1 \%$ ash content, $35.1-35.4 \%$ calcium, $0.12 \%$ phosphorus, $0.15-0.17 \%$ sodium, $0.37-0.40 \%$ magnesium, $0.10-0.13 \%$ potassium and $0.09-0.19 \%$ sulphur and trace of iron, zinc and copper. When the calcium from the shell is removed, the organic matrix material is left behind. This organic material has a calcium binding properties and its organization during the formation influences the strength of the shell. The organic material must be deposited so that the size-and organization of the crystalline components (mostly calcium carbonate) are ideal, thus, leading to a strong shell [2].

There are other zones that are involved in the selforganization giving the shell its strength. It must be recommended that many factors can influence the amount of calcium being laid down by the hen. Just because an eggshell is thick does not necessarily mean that it is strong.
Sometimes a thinner eggshell is stronger than a thicker eggshell. The reason for this is due to the shape and organization of the organic and inorganic components of the shell [3].

Of course the source of calcium for shell formation is a subject of interest. The origin of hen's calcium dietary, but female birds has mechanisms for making large amounts of calcium available over relatively short time. The hen deposit $2 \mathrm{~g}$ of calcium on egg in 15 hours. This is equivalent to removing the total amount of circulating calcium every 15 minutes during shell formation. Many birds lay uniformly colored by pigments derived from the red blood cells. These porphyrin pigments are distributed throughout the shell, but are more concentrated in its outer layer [1]. On a freshly laid wet egg, the cuticle and cuticular pigments can easily be rubbed off. It is interesting to note that the eggs from particular birds often have a uniform pattern day after day. In laying hen, medullary bone is in a dynamic state continuously being deposited and broken down. A sizeable fraction of each shell's calcium is derived from this source. Actual shell formation involves the secretion of calcium into the shell gland lumen by uterine epithelial cells, the secretion of a carbonate (bicarbonate ions) source by the sub epithelia tabular glands, and the interaction of these components to form calcium carbonate. Insufficient calcium can lead to faulty shell formation, as it can inhibit the enzyme carbonic anhydrase, which catalyzes the conversion of $\mathrm{CO}_{2}$ and $\mathrm{H}_{2} \mathrm{O}$ to weak acid [4].

\section{Materials and Methods}

Sample Collection: Ten of each of the fresh samples were obtained from Sokoto State Central Market, Nigeria. The samples were picked at random (Asaolu and Asaolu, 2002). The samples are labeled as: Sample A(Poultry fowl's eggshell), Sample B(Guinea fowl's eggshell), Sample C(Chicken's eggshell) and Sample D(Pigeon's eggshell). 


\section{International Journal of Science and Research (IJSR) \\ ISSN (Online): 2319-7064 \\ Index Copernicus Value (2013): 6.14 | Impact Factor (2013): 4.438}

Each of the four samples was washed with distilled water and all of the membranes were peeled off from the inside of the shell, the shell was then dried under shade and grinded into a fine powder using a mortar and then sieved and kept in an air tight container.

\subsection{Proximate Analysis}

Ash content was determined at $650^{\circ} \mathrm{C}$. Moisture content was determined at $105^{\circ} \mathrm{C}$ in accordance with Oyeleke method[5].
Fibre was also determined by means of Oyeleke's method. Crude nitrogen was determined by means of KJeldahl method and crude protein was obtained by multiplying the value of nitrogen with a protein conversion factor 6.25 . Both lipid and fibre were determined according to the work of AOAC (1990) [6], while carbohydrate was estimated from: $\mathrm{CHO}=100-(\%$ ash $+\%$ crude lipid $+\%$ crude protein + \%fibre) [7].

Table 1: Proximate content of the samples

\begin{tabular}{|l|l|l|l|l|}
\hline Composition(\% weight) & Sample A & Sample B & Sample C & Sample D \\
\hline Moisture & $1.0 \pm 0.007$ & $2.0 \pm 0.020$ & $0.5 \pm 0.030$ & $3.0 \pm 0.010$ \\
\hline Ash & $47 \pm 0.015$ & $47.5 \pm 0.020$ & $43.5 \pm 0.032$ & $44.5 \pm 0.020$ \\
\hline Crude fibre & $5.0 \pm 0.500$ & $3.5 \pm 1.230$ & $3.0 \pm 0.300$ & $2.5 \pm 0.080$ \\
\hline Crude protein & $1.4 \pm 0.400$ & $1.6 \pm 0.200$ & $1.35 \pm 0.400$ & $1.33 \pm$ ND \\
\hline Carbohydrate & $46.1 \pm 0.200$ & $44.9 \pm 0.200$ & $51.7 \pm 0.440$ & $51.2 \pm 0.110$ \\
\hline
\end{tabular}

\subsection{Mineral Analysis}

The samples were digested into solution by wet digestion using a mixture of conc. Nitric, perchloric and sulphuric acids in the ratio 10:3:2 respectively. $0.2 \mathrm{~mL}$ of each sample was taken into $50 \mathrm{~mL}$ volumetric flask followed by addition of $20 \mathrm{~mL}$ of distilled water. The flame photometer was switched on and various filters for different elements were selected and then determined. However calcium and magnesium were determined using complexometric titration using EDTA at $\mathrm{pH} 10$ buffer solution in order to prevent the interference of ions like $\mathrm{Cu}^{2+}$ and $\mathrm{Fe}^{2+}$ from forming a complex with EDTA. Murexide indicator was used and the end points were determined in all the samples

Table 2: Calcium carbonate content of the samples

\begin{tabular}{|l|l|l|l|l|}
\hline Composition(\% weight) & Sample A & Sample B & Sample C & Sample D \\
\hline$\% \mathrm{CaCO}_{3}$ & 76.00 & 79.30 & 73.54 & 69.74 \\
\hline
\end{tabular}

Table 3: Mineral composition of the samples (mg/100g in dry weight)

\begin{tabular}{|c|c|c|c|c|}
\hline Elements & Sample A & Sample B & Sample C & Sample D \\
\hline $\mathrm{Na}$ & $5.625 \pm 0.2$ & $5.000 \pm 0.2$ & $4.750 \pm 1.0$ & $5.475 \pm 0.3$ \\
\hline $\mathrm{K}$ & $7.950 \pm 0.2$ & $8.25 \pm 1.0$ & $9 . .000 \pm 2.0$ & $13.00 \pm 1.6$ \\
\hline $\mathrm{Ca}$ & $0.3625 \pm 0.1$ & $0.474 \pm 0.2$ & $0.400 \pm 0.1$ & $0.325 \pm 0.2$ \\
\hline $\mathrm{Mg}$ & $0.0375 \pm \mathrm{ND}$ & $0.0375 \pm 0.1$ & $0.0375 \pm 0.2$ & $0.025 \pm 0.1$ \\
\hline $\mathrm{P}$ & $7.0475 \pm 0.005$ & $6 . .6775 \pm 0.0213$ & $6.955 \pm 0.005$ & $6.432 \pm 0.005$ \\
\hline $\mathrm{Fe}$ & 3.4 & 4.5 & 2.9 & 2.5 \\
\hline $\mathrm{Zn}$ & 3.2 & 3.4 & 2.0 & 1.4 \\
\hline $\mathrm{Cu}$ & 0.46 & 0.31 & 0.42 & 0.13 \\
\hline
\end{tabular}

Table 4: Qualitative Result

\begin{tabular}{|c|c|c|c|c|}
\hline Elements Determined & Sample A & Sample B & Sample C & Sample D \\
\hline Chloride $\left(\mathrm{Cl}^{-}\right)$ & + & + & + & + \\
\hline Sulfate $\left(\mathrm{SO}_{4}{ }^{2-}\right)$ & + & + & + & - \\
\hline Carbonates $\left(\mathrm{CO}_{3}{ }^{2-}\right)$ & + & + & + & + \\
\hline Nitrate $\left(\mathrm{NO}_{3}{ }^{2-}\right)$ & + & + & + & + \\
\hline
\end{tabular}

$+=$ Present

\section{Result and Discussion}

Table 1 shows that sample $\mathrm{C}$ outstood among the remaining samples in terms of very low moisture content $(0.5 \%)$. This is an indication that it can be stored for a very long time, since high percentage of moisture can cause microbial activities during storage [8]. Interms of the inorganic content in biological system, that is the ash content (Mc Donald et al 1981), sample B is having the highest percentage among all. This shows that it can be used as a supplement of inorganic content during feeding. As for the crude fibre, the higher the fibre content, the more it helps to satisfy the appetite and assist in moving food through the alimentary canal by aiding the muscular action of intestine. Thus, preventing constipation.So, by comparing the four samples, though they are having low percentages, sample $\mathrm{A}$ is having the highest percentage, therefore, it can be used as a food supplement. The percentage crude protein of sample B was found to be higher. This shows that it can be used in the body for the utilization of energy more than the remaining samples. As for carbohydrates, sample $\mathrm{C}$ is having the highest percentage $(51.65 \%)$ which is an indication that it is the best energy given food compared to the remaining samples. Therefore, it will be more important in the production of soft bulky stool. Lipid is very important in the body; it is serving as thermal

\section{Volume 4 Issue 3, March 2015}




\section{International Journal of Science and Research (IJSR) \\ ISSN (Online): 2319-7064 \\ Index Copernicus Value (2013): 6.14 | Impact Factor (2013): 4.438}

insulator. From the table, sample B is having greater percentage of lipid; therefore, it can be used as a source of lipid though it was found to be low. From table 2, the result obtained showed that the sample B is having the highest percentage of calcium carbonate; this sample can be used as an attractive source of calcium carbonate and can be used as a supplement in formulating animal feeds. From table 3, it was found that the eggshells are rich in mineral elements. Sodium was found to be greater in quantity in sample A, therefore it can be used as a supplement because sodium is important mineral element which help in salt formation in the body and in neuromuscular transmission. Calcium and magnesium which are often found together, they happen to be higher in sample B, therefore, calcium can be used as a supplement in bone development while on the other hand the magnesium contents of sample A,B,C coincides, that means both the three samples can be used in bones development and so also the muscles. Phosphorus content, sample $\mathrm{A}$ is having the largest content that is appreciable amount required daily for proper physiological function such as bone formation, nucleotide for enzymes activities, ATP, ADP phosphate and energy transmitting forming system [9]. Potassium content for sample D was found to be higher than that of the remaining samples. Therefore, it can be used as a supplement in regulating neuromuscular excitability and muscles contraction and also for the activation of a wide variety of important enzymes [9]. The iron content of sample $\mathrm{B}$ was found to be highest among the remaining three samples. Therefore, sample B can be used as a supplement in the body for oxygen transport by hemoglobin and enzymatic oxidation reactions [10]. Zinc was found in higher quantity in sample B, this can be used together with soya beans and magnesium to improve the quality of eggshell in laying hens [11]. The copper content was found to be very low. This indicates that all the samples are having low copper content which is very important mineral element, helps in muscles, nerve and oxidase enzymes in the body [12]. From table 4, the entire four samplescontain carbonates and generally, carbonates and organic matter constitute the skeleton of eggshells [13]. For chlorides, although not determined quantitatively, Chlorides are found qualitatively in all the four samples, chlorides decreases the measure of eggshell quality only for hens receiving calcium, and calcium improved both measures only for hens [14].

\section{Conclusion}

It has been reported that calcium is an essential nutrient for avian reproduction. Calcium rich foods are consumed by breeding birds for production of eggshells and for provisioning chicks that are mineralizing skeletal tissues. From the fore going analyses and discussion made, it has been found out that, there is high amount of calcium carbonate $\left(\mathrm{CaCO}_{3}\right)$ in virtually all the samples analyzed, an average of $75 \%$ was found to be present. The following provides an example of what could be done based on the studies by Froning and Bergquist (1990). Eggshells was ground, $(70 \%)$ and blended with technical albumin $(8 \%)$, maize $(5 \%)$, soya beans meal $(17 \%)$ and propionic acid $(0.15 \%)$. This blend can be extruded, cooled and fed to laying hens as a protein and calcium supplement in a fully formulated diet. Other possible uses of eggshells uses include the membrane free shell powder used in paper industries and in agriculture as lime substitute or calcium supplement.

\section{References}

[1] Aitken, R.N.C. The oviduct in D.J bell and B.M. Freeman, Physiology and Biochemistry of Domestic fowl. Vol.3. Academic, London, 1971.

[2] www.ruessheim.chem/eggcontent.html

[3] Hammond, R.W, Burke, W.H., Hertelendy, F. Influence of follicular maturation on progesterone Release in chicken granulose cells in response to turkey and ovine gonadotropins. Biol.Reprod.24:1048:55, 1981.

[4] Lake, P.E. The male in reproduction.In D.J. Bell and B.M. Freeman. Physiology and Biochemistry of domestic forol, vol 3. Academic, London, 1971.

[5] Oyeleke, O.A. Outline of food analysis. ABU Press Nigeria.Pp. 79, 1984.

[6] AOAC, Official methods of analysis (15th Edn.). Washington D.C USA. Association of OfficialAnalytical Chemists inch. 400-2200 Wilson Boulevard, Arlington Virginia USA., 2: 910-928, 1990.

[7] Hassan, L.G., S.M. Dangoggo, K.J. Umar, I. Saidu and F.A. Folorunsho, Proximate, minerals and antinutritional factors of Danielliaoliveri seed kernel. Chemclass J., 5: 31-36, 2008.

[8] Froning, G.W. and BERGQUIST, D. Research Noto: utilization of inedible eggshells and technical egg white using extension technology, poultry science, 69, 20512053, 1990.

[9] Ladan, M.J. Bilbis, L.S and Lawal, M. Nutrient composition of some green leafy vegetables in sokoto, Nigeria. Journal of basic and applied science 5, 39-44, 1996.

[10] Michelle, H.H. Comparative Nutrition of man and domestic Animals vol. 1., academic press NewYork and London. Pp 41, 1962

[11] A Zamani, HR Rahmani, J Pourreza - Pak. J. Biol. Sci, docsdrive.com, 2005.

[12] TACON A.G.J. Utilization of chick hatchery waste: The nutritional characteristics of day old chicks and eggshells agricultural waste, 4, 335-343, 1995.

[13] KChojnacka - Journal of hazardous materials, Elsevier, 2005.

[14]R. E. AUSTIC and K. KESHAVARZPoultry Science 67 (5): 750-759, 1988.

\section{Autor Profile}

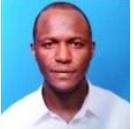

Nasruddeen Yusuf Al-awwal was born on $23^{\text {rd }}$ August, 1983 at Jefferson City, Missouri, USA. He graduated from UsmanuDanfodiyo University Sokoto, Nigeria where he obtained his B.Sc. in applied chemistry, 2005. He is working with CAS Kano, Nigeria as Lecturer II and currently pursuing M. Sc. Organic Chemistry at SRM University Kattankulathur-603203. India. 